\title{
LV. Process for preventing and correcting an imperfection in wines, known by the name of ropiness
}

\section{Herpin}

To cite this article: M. Herpin (1821) LV. Process for preventing and correcting an imperfection in wines, known by the name of ropiness, Philosophical Magazine Series 1, 58:282, 254-254, DOI: $10.1080 / 14786442108652617$

To link to this article: http://dx.doi.org/10.1080/14786442108652617

曲 Published online: 27 Jul 2009.

Submit your article to this journal $\pi$

Џll Article views: 2

Q View related articles $₫$ 
form a calorific focus at yet a greater distance, light not being converted into heat until it is reflected.

In my next I shall endeavour to support Leibnitz's Theory of Refraction, and shall give some new experiments with the prism. Sir, I remain

Cork, May 24, 1821.

Your obedient servant, J. REAJE, M.D.

LV. Process for preventing and correcting an Imperfection in Wines, known by the Name of Ropiness. By M. Herpin*.

$\mathbf{R}$ Ropiness of wines is a kind of spontaneous decomposition which gives them a consistence similar to that of oil. The wine attacked by ropiness becomes flat and insipid; it turns yellow when poured out, runs in a thread like oil, and loses its natural fluidity. It froths with difficulty by agitation, and disagrees with the stomach. This alteration, which attacks wines during their insensible fermentation, is the more injurious as the alcohol already formed is destroyed to enter into new combinations : ropy wine, therefore, submitted to distillation, gives but a small quantity of brandy, which is of a bad quality, and which has a taste so much the more empyreumatic as the wine distilled is more mucilaginous.

It is remarked that white-wines seldom turn ropy while in cask, but that they do frequently when in bottle.

The remedy for recovering ropy wine, consists in dissolving from six to twelve ounces of acidulous tartrite of potash (cream of tartar), and an equal quantity of coarse sugar, in a gallon of wine heated to bolling. This mixture is to be poured warm into the ropy wine, the cask is to be stopped up and shaken for five or six minutes, and then put in its place with the bung turned downward. After resting for a day or two in that position, the cask is to be turned and the wine fined in the usual way; but instead of stirring it through the bung-hole, as commonly practised, the cask is to be shaken for a few minutes and put in its place with the bung turned up. In four or five days the wine will be clear, dry, limpid, and completely freed from ropiness; but as it cannot safely remain upon the sediment, it must be drawn off, after which it will not be liable to become ropy again. If the ropy wine is in bottles, they should be emptied into a cask, to undergo the preceding operation.

* From Bulletin de la Société d'Encouragement.

LVI. On 